\title{
Effects of feeding three types of corn-milling coproducts on milk production and ruminal fermentation of lactating Holstein cattle
}

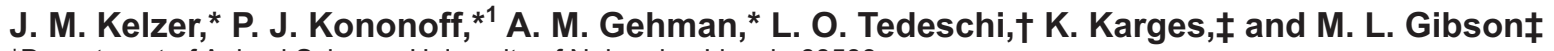 \\ ${ }^{*}$ Department of Animal Science, University of Nebraska, Lincoln 68583 \\ †Department of Animal Science, Texas A\&M University, College Station 77843-2471 \\ ‡Dakota Gold Research Association, Sioux Falls, SD 57104
}

\section{ABSTRACT}

Two experiments were conducted to determine the effects of feeding 3 corn-milling coproducts on intake, milk production, ruminal fermentation, and digestibility of lactating Holstein cows. In experiment 1, three corn-milling coproducts were fed at $15 \%$ of the diet dry matter (DM) to 28 Holstein cows averaging $( \pm \mathrm{SD}) 625$ $\pm 81 \mathrm{~kg}$ of body weight and $116 \pm 33 \mathrm{~d}$ in milk to determine effects on DM intake and milk production. In experiment 2 , the same rations were fed to 4 ruminally fistulated, multiparous Holstein cows averaging $677 \pm$ $41 \mathrm{~kg}$ of body weight and $144 \pm 5 \mathrm{~d}$ in milk to determine the effects on ruminal fermentation and digestibility. In both experiments, cows and treatments were assigned randomly in $4 \times 4$ Latin squares over four 21 -d periods. Treatments were formulated by replacing portions of forage and concentrate feeds with $15 \%$ coproduct and included 1) 0\% coproduct (control), 2) dried distillers grains plus solubles (DDGS), 3) dehydrated corn germ meal (germ), and 4) high-protein dried distillers grains (HPDDG). Feed intake was recorded daily, and milk samples were collected on d 19 to 21 of each period for analysis of major components. Rumen fluid was collected at 10 time points over $24 \mathrm{~h}$ post feeding on $\mathrm{d}$ 21 of experiment 2 . In experiment $1, \mathrm{DM}$ intake was greater for the germ $(24.3 \mathrm{~kg} / \mathrm{d})$ and DDGS treatments $(23.8 \mathrm{~kg} / \mathrm{d})$, but DDGS was not different from the control $(22.9 \mathrm{~kg} / \mathrm{d})$ and HPDDG treatments $(22.4 \mathrm{~kg} / \mathrm{d})$. Milk production paralleled DM intake and tended to be greater for the germ $(32.1 \mathrm{~kg} / \mathrm{d})$ and DDGS treatments $(30.9 \mathrm{~kg} / \mathrm{d})$, but the DDGS treatment was not different from the control $(30.6 \mathrm{~kg} / \mathrm{d})$ and HPDDG treatments $(30.3 \mathrm{~kg} / \mathrm{d})$. However, yields of milk fat, milk protein, and $3.5 \%$ FCM were similar and averaged $( \pm$ SEM) 1.1 $\pm 0.1,0.9 \pm 0.03$, and $31.7 \pm 1.3 \mathrm{~kg} / \mathrm{d}$. Milk urea nitrogen was greater for the HPDDG $(15.9 \mathrm{mg} / \mathrm{dL})$ and germ treatments $(15.5 \mathrm{mg} / \mathrm{dL})$ than for the control $(15.0 \mathrm{mg} / \mathrm{dL})$ and DDGS treatments $(14.9 \mathrm{mg} / \mathrm{dL}) . \mathrm{In}$

Received March 13, 2009.

Accepted June 11, 2009

${ }^{1}$ Corresponding author: pkononoff $2 @ u n l . e d u$ experiment 2, DM intake and milk production were not different across treatments and averaged $26.1 \pm 2.3$ and $28.3 \pm 3.9 \mathrm{~kg} / \mathrm{d}$. Ruminal $\mathrm{pH}(6.26 \pm 0.08)$ and total concentration of volatile fatty acids $(125.3 \pm 4.2 \mathrm{mM})$ were similar. Acetate concentration was higher for the control treatment than the DDGS, germ, and HPDDG treatments ( 81.7 vs. $75.8,75.0$, and $78.4 \mathrm{mM}$ ). Concentrations of propionate and butyrate were not different and averaged $27.8 \pm 1.2$ and $14.3 \pm 0.9 \mathrm{~m} M$ across treatments. The acetate:propionate ratios for the control, germ, and HPDDG treatments were greater than for the DDGS treatment (3.02, 2.88, and 2.91 vs. 2.62). Dry matter, organic matter, and neutral detergent fiber digestibilities were similar across treatments and averaged $63.5 \pm 2.7,67.3 \pm 2.2$, and $43.5 \pm 4.2 \%$. Milk production followed DM intake in experiment 1, and yield of major milk components was not affected. Results of these experiments indicate that dairy rations can be successfully formulated to include $15 \%$ of diet DM as corn-milling coproducts while maintaining or increasing DM intakes and yields of milk and milk components.

Key words: coproduct, dairy, milk production, ruminal fermentation

\section{INTRODUCTION}

Growth and technological advancement in the cornethanol production process has prompted changes in how ethanol is produced from corn grain. These changes have also resulted in changes in the nature and chemical composition of corn-milling coproducts (Ponnampalam et al., 2004; Murthy et al., 2006). For example, one process replaces the heating and cooking steps before fermentation with raw starch hydrolysis (Wang et al., 2007). An additional process separates the corn kernel into its 3 main components (germ, bran, and endosperm) before fermentation. In this process, the separated germ and bran are considered corn-milling coproducts and are used as animal feed, whereas the starch-containing endosperm enters the industrial fermentation process (Corredor et al., 2006; Murthy et al., 2008). As the fermentation process proceeds, the resulting coproduct is recovered and is highly concentrated in 
$\mathrm{N}$. Each of these coproducts is unique because each has less exposure to high temperatures during processing.

Several studies have demonstrated that compared with a control diet without coproducts, feeding traditional coproducts, such as dried distillers grains plus solubles or wet corn gluten feed, results in increased intake and enhanced milk yield when fed to Holstein dairy cows (Nichols et al., 1998; VanBaale et al., 2001; Leonardi et al., 2005). However, research evaluating diets formulated to contain newly available coproducts is limited. The objectives of this research were to compare rations containing 1 of 3 corn-milling coproducts with a control ration not containing any coproducts and to evaluate the effects of diet on digestibility and milk production. Given the unique chemical composition of each of these coproducts, a different substitution strategy was used for each treatment diet; thus, the primary aim was to compare each diet containing a coproduct with the control diet not containing any.

\section{MATERIALS AND METHODS}

\section{Experiment 1: Animals, Experimental Design, and Treatments}

Twenty lactating Holstein cows averaging $( \pm$ SD) 111 $\pm 38 \mathrm{DIM}$ and $653 \pm 70 \mathrm{~kg}$ of BW and 8 lactating Holstein heifers averaging $129 \pm 12$ DIM and $556 \pm$ $65 \mathrm{~kg}$ of BW were randomly assigned to seven $4 \times 4$ Latin squares. Within a square, animals were stratified by parity and milk production, and treatments were assigned randomly according to the method of Kononoff and Hanford (2006). During each of the four 21-d periods, cows were offered 1 of 4 TMR that differed by type of corn-milling coproduct, included at $15 \%$ of diet DM. The 4 dietary treatments were as follows: first, the control included no coproducts, and second, DDGS included distillers dried grains plus solubles (DG) at $15 \%$ of the diet DM (Northstar Ethanol LLC, Lake Crystal, MN). The distillers grains plus solubles used in this treatment resulted from the corn-ethanol production process in which heating before fermentation was replaced with enzymatic digestion. The third treatment (hereafter, termed "germ") was formulated to contain corn germ meal (TCE LLC, Coon Rapids, IA) that was removed from the corn kernel before fermentation. The fourth treatment diet (HPDDG) was formulated to contain the corn-milling coproduct high-protein distillers dried grains (HP; TCE LLC, Coon Rapids, IA), resulting from fermentation of primarily endosperm. Treatments were formulated with the CPM-Dairy model (version 3.0) to meet or exceed requirements as estimated by the CPM-Dairy model (Boston et al., 2000).
A brief rationale for the formulated treatment diets follows. The control diet was formulated to be similar to a dairy diet fed in the Great Plains region of the United States. This ration did not contain any corn-milling coproducts and was largely composed of ingredients such as corn silage, ground corn, alfalfa, soybean meal, and soyhulls, which are produced locally. Given the high concentration of fiber and protein contained in corn distillers grains, DG were included at $15 \%$ of the ration $\mathrm{DM}$, and this largely replaced the alfalfa and soybean meal. A portion of ground corn was also replaced to compose the DDGS treatment. The formulation of the germ treatment ration was similar, but given the lower concentration of protein and higher concentration of starch in the corn germ, more soybean meal and less corn was included. Given the high-protein content of HP, the HPDDG diet was formulated to contain less alfalfa and soy-based protein. Brome hay was added to each treatment diet in an attempt to increase the concentration of effective fiber. Treatments were mixed separately and fed to individual cows by using a small drum mixer (Data Ranger, American Calan Inc., Northwood, NH).

\section{Experiment 2: Animals, Experimental Design, and Sample Collection}

After completion of the first study, experiment 2 was conducted. Four ruminally fistulated Holstein cows averaging $144 \pm 5$ DIM and $677 \pm 41 \mathrm{~kg}$ of BW were assigned randomly to 1 of 4 treatments in one $4 \times 4$ Latin square according to the method of Kononoff and Hanford (2006). Treatments were formulated, mixed, and fed using the same procedures as described for experiment 1 . Days 1 to 17 of each period were used for dietary adaptation, and d 18 to 21 were used for data collection. On d 18 to 21 , urine and fecal samples were collected at 0600 and $1800 \mathrm{~h}$ before milking. Urination upon stimulation and rectal grab sample techniques were used to collect urine and feces. Thirty milliliters of urine was acidified with $4 \mathrm{MHCl}$ to $\mathrm{pH}<4$ for preservation before immediately being frozen $\left(-20^{\circ} \mathrm{C}\right)$ for later analyses. Fecal samples (approximately $200 \mathrm{~g}$ wet wt) were also immediately frozen $\left(-20^{\circ} \mathrm{C}\right)$ for later analyses. On d 21 of each period, ruminal fluid samples were collected over 10 time points $(0,1,2,4,6,8,11$, 14,18 , and $23.5 \mathrm{~h}$ ) post feeding. Ruminal grab samples were taken from the cranial, caudal, left lateral, and right lateral areas of the rumen to obtain a representative sample, were mixed to become uniform, and were strained through 4 layers of cheesecloth to obtain rumen fluid. Rumen fluid $\mathrm{pH}$ was measured immediately and directly by using a handheld $\mathrm{pH}$ electrode (model M90, Corning Inc., Corning, NY), and $30 \mathrm{~mL}$ of ruminal fluid 
was immediately stored in plastic, screw-capped, 50-mL conical tubes and frozen $\left(-20^{\circ} \mathrm{C}\right)$ for later analyses.

\section{Animal Care and Measurements, Milk Collection, and Feed Sampling}

All experimental procedures were approved and cows were cared for according to guidelines stipulated by the University of Nebraska Institutional Animal Care and Use Committee. During both experiments, cows were housed in individual stalls and milked at 0730 and 1930 h. On d 19 to 21 of each period, milk samples were collected during the a.m. and p.m. milkings and preserved using 2-bromo-2-nitropropane-1,3-diol. Milk samples were sent to Heart of America DHIA in Manhattan, Kansas, for laboratory analyses of fat, true protein, lactose, SNF, and MUN. Milk true protein, fat, and lactose contents were analyzed for each sample by nearinfrared spectroscopy (Bentley 2000 Infrared Milk Analyzer, Bentley Instruments, Chaska, MN), and yields were reported and weighted according to milk volume and time of collection. Chemical methodology based on a modified Berthelot reaction was used to determine MUN concentration (ChemSpec 150 Analyzer, Bentley Instruments).

Cows were individually fed at $0900 \mathrm{~h}$ for ad libitum consumption and approximately $10 \%$ refusal. Weight of the feed offered to cows each day was recorded, and refused feed was individually removed and weighed each day at $0800 \mathrm{~h}$. Daily intake was recorded on individual cows by subtracting the feed refusal amount from the total amount fed the previous day. Throughout the experiment, DM content was analyzed on corn silage and alfalfa haylage once per week by using a microwave oven (Heinrichs and Ishler, 2000). Diet ingredient proportions were adjusted accordingly if the DM of the forages changed. Total mixed ration, forage, and concentrate samples were collected on d 20 to 21 of each period. Samples of corn-milling coproducts included in the grain mixes were obtained 3 times throughout the experiment. All cows were individually weighed on d 20 to 21 immediately after the a.m. milking, and weights were averaged for each period. Cows were scored for body condition by a single trained individual on d 21 of each period by using a scale of 1 (extremely thin) to 5 (extremely fat) according to the method of Wildman et al. (1982).

\section{Forage, Coproduct, TMR, Fecal, Urine, and Rumen Fluid Sample Analyses}

Subsamples of forages, corn-milling coproducts, and diets from experiment 1 were sent to Dairy One Forage Analysis Laboratory (Ithaca, NY) for chemical analy- sis. The analyses reported during each period included DM (AOAC, 2000; method 930.15), CP (AOAC, 2000; method 990.06), soluble protein (Roe and Sniffen, 1990), NDF and ADF (Van Soest et al., 1991; without sodium sulfite, using an Ankom Fiber Analyzer, Ankom Technology, Fairport, NY, and with $100 \mu \mathrm{L} / 0.50 \mathrm{~g}$ of sample heat-stable $\alpha$-amylase, no. A3306, Sigma Chemical Co., St. Louis, MO), lignin (AOAC, 2000; method 973.18 D), starch (Smith, 1969), ash (AOAC, 2000; method 942.05), ether extract (AOAC, 2000; method 2003.05), and minerals ( $\mathrm{Ca}, \mathrm{P}, \mathrm{S}, \mathrm{Mg}, \mathrm{K}, \mathrm{Na}, \mathrm{Fe}, \mathrm{Zn}, \mathrm{Cu}, \mathrm{Mn}$, and Mo; Sirois et al., 1994). Total mixed ration samples from experiment 2 were analyzed for chemical composition (DM, CP, NDF, ADF, ash, ether extract, NFC, and starch) in the University of Nebraska Ruminant Nutrition Laboratory (Lincoln, NE). Particle size distribution of the rations were analyzed using the Penn State Particle Separator (Kononoff et al., 2003). Samples of TMR were dried for $48 \mathrm{~h}$ in a $60^{\circ} \mathrm{C}$ forced-air oven to determine DM (AOAC, 1996) and ground through a 1-mm screen (Wiley mill, Arthur H. Thomas Co., Philadelphia, PA). Fecal samples from experiment 2 were thawed and composited by cow and period before complete drying in a $60^{\circ} \mathrm{C}$ forced-air oven.

Laboratory DM of the TMR and fecal samples was determined in a $100^{\circ} \mathrm{C}$ oven for $12 \mathrm{~h}$ (AOAC, 1996). Percentage of ash was determined by incinerating the samples in a $600^{\circ} \mathrm{C}$ ash oven for $6 \mathrm{~h}$ (AOAC, 1996), and OM was calculated as (100 - \% ash). Percentage of N was estimated for the TMR and fecal samples using the combustion method (AOAC, 1996) in a combustion $\mathrm{N}$ analyzer (Leco FP-528, Leco Corp., St. Joseph, MI). Neutral detergent fiber and ADF (Van Soest et al., 1991) concentrations were determined on all samples with an Ankom Fiber Analyzer (Ankom Technology). The procedure was modified not to include sodium sulfite and to include heat-stable $\alpha$-amylase (no. A3306, Sigma Chemical Co.) at $100 \mu \mathrm{L} / 0.50 \mathrm{~g}$ of sample. In addition, samples of TMR were analyzed for starch (Total Starch Assay, Megazyme International, Co. Wicklow, Ireland).

The internal marker used in this experiment to determine nutrient digestibility was indigestible ADF (IADF; Huhtanen et al., 1994). Approximately $1.25 \mathrm{~g}$ of 1-mm ground subsamples of TMR and fecal samples from experiment 2 were weighed (in triplicate) into $5 \times 10 \mathrm{~cm}$ Dacron nylon bags (Ankom Technology) possessing a pore size of $50 \mu \mathrm{m}$. The bags were then heat-sealed with an Ankom Heat Sealer (Vanzant et al., 1998). Fifty Dacron bags each were placed into larger nylon mesh bags $(36 \times 42 \mathrm{~cm})$ that contained 2 secured 100 -g weights before rumen incubation.

Nylon mesh bags were incubated for $12 \mathrm{~d}$ in the ventral sac of the rumen of a ruminally fistulated steer 
fitted with a flexible ruminal cannula. The steer was of Angus-cross breeding, weighed $418 \mathrm{~kg}$, and was limit-fed $7.4 \mathrm{~kg}$ of DM of a mixed diet containing $70 \%$ grass hay, $15 \%$ ground corn, and $15 \%$ soybean meal daily. The animal was housed in an individual pen in a temperature-controlled room and had free access to water and no access to the outside. Nylon bags were removed after $12 \mathrm{~d}$, and Dacron bags were machine washed using five 3 -min cycles consisting of a 1-min wash and a 2-min spin; rinsed in distilled water, forcing all residues to the bottom; rolled; and dried for 12 $\mathrm{h}$ at $55^{\circ} \mathrm{C}$ (AOAC, 1996). After drying, ADF content was determined gravimetrically (Van Soest et al., 1991) with an Ankom Fiber Analyzer (Ankom Technology). The procedure was modified not to include sodium sulfite and to include heat-stable $\alpha$-amylase (no. A3306, Sigma Chemical Co.) at $100 \mu \mathrm{L} / 0.50 \mathrm{~g}$ of sample. Total fecal output was calculated by determining intake of IADF and dividing intake of IADF by IADF concentration in the feces. Whole-diet total digestible nutrient (TDN) concentrations were then determined (Weiss et al., 1992), and based on these values, production levels of digestible energy, $\mathrm{ME}$, and $\mathrm{NE}_{\mathrm{L}}$ were calculated as outlined by the NRC (2001).

Urine samples collected in experiment 2 were thawed and composited by cow and period. Nitrogen content was determined by using the Dumas combustion method (AOAC, 1996) in a combustion $\mathrm{N}$ analyzer (Leco FP-528, Leco Corp.). Urine samples were diluted with 19 parts urine diluent to 1 part urine. The urine diluent was composed of $0.202 \%$ sodium 1-heptane sulfonic acid and $0.086 \%$ ammonium dihydrogen phosphate. The solution was brought to $\mathrm{pH} 2.1$ with $4 \mathrm{M} \mathrm{HCl}$. Diluted urine samples were analyzed for the purine derivatives (PD) of allantoin, uric acid, xanthine, hypoxanthine, and creatinine by HPLC (Waters Corp., Milford, MA) according to the procedures of Shingfield and Offer (1999). The ratio of PD to creatinine has been used to illustrate relative differences in microbial CP flow to the duodenum (Gonda, 1995; Shingfield and Offer, 1998). Based on estimates of urinary excretion of PD, the microbial protein supply was estimated according to the method of Chen and Gomes (1992). Creatinine concentration was used as a marker to estimate total urine output volume (Valadares et al., 1999; Leonardi et al., 2003). Urine volume was calculated by assuming that creatinine output averaged $28 \mathrm{mg} / \mathrm{kg}$ of BW, as estimated by Whittet (2004). Similar daily creatinine outputs, ranging from 25 to $30 \mathrm{mg} / \mathrm{kg}$ of $\mathrm{BW}$, have been reported previously (McCarthy et al., 1983; Jones et al., 1990).

Rumen fluid samples collected during experiment 2 were thawed and centrifuged at 5,000 $\times g$ for $10 \mathrm{~min}$ before analyses for ammonia- $\mathrm{N}$ and VFA concentra- tions. Ruminal fluid ammonia- $\mathrm{N}$ was determined according to procedures reported by Broderick and Kang (1980), using a SPECTRAmax 250 spectrophotometer (Molecular Devices Corp., Sunnyvale, CA). Ruminal fluid VFA concentrations were determined according to the method of Yang and Varga (1989) by using a gas chromatograph (HP5890 Series II, Hewlett-Packard Co., Palo Alto, CA).

Statistical Analysis: Experiment 1. Performance data were analyzed as a replicated $4 \times 4$ Latin square using the MIXED procedures of SAS (Version 9.1, SAS Institute Inc., Cary, NC). Fixed model effects included square, period within square, and treatment, and the random effect was cow within square. The linear model for this experiment is written as follows:

$$
\mathrm{y}_{\mathrm{ijkm}}=\mu+\tau_{\mathrm{m}}+\beta(\tau)_{\mathrm{im}}+\rho(\tau)_{\mathrm{jm}}+\alpha_{\mathrm{k}}+\varepsilon_{\mathrm{ijkm}},
$$

where $\mathrm{y}_{\mathrm{ijkm}}$ represents observation ${ }_{\mathrm{ijkm}} ; \mu$ represents the overall mean; $\tau_{\mathrm{m}}$ represents the fixed effect of square $\mathrm{m}$; $\beta(\tau)_{\text {im }}$ represents the random effect of cow $i$ within square $\mathrm{m} ; \rho(\tau)_{\mathrm{jm}}$ represents the fixed effect of period $\mathrm{j}$ within square $\mathrm{m}$; and $\alpha_{\mathrm{k}}$ represents the fixed effect of treatment $\mathrm{k}$. The residual term $\varepsilon_{\mathrm{ijkm}}$ was assumed to be normally, independently, and identically distributed, with variance $\sigma_{e}^{2}$.

Statistical Analyses: Experiment 2. Performance data were analyzed as a $4 \times 4$ Latin square using the MIXED procedures of SAS (Version 9.1; SAS Institute Inc.). Fixed model effects included treatment and period with cow as the random effect. The linear model for this experiment is written as follows:

$$
\mathrm{y}_{\mathrm{ijk}}=\mu+\beta_{\mathrm{i}}+\rho_{\mathrm{j}}+\alpha_{\mathrm{k}}+\varepsilon_{\mathrm{ijk}},
$$

where $y_{\mathrm{ijk}}$ represents observation ${ }_{\mathrm{ijk}} ; \mu$ represents the overall mean; $\beta_{\mathrm{i}}$ represents the random effect of cow $\mathrm{i}$; $\rho_{\mathrm{j}}$ represents the fixed effect of period $\mathrm{j}$; and $\alpha_{\mathrm{k}}$ represents the fixed effect of treatment $\mathrm{k}$. The residual term $\varepsilon_{i j k}$ was assumed to be normally, independently, and identically distributed, with variance $\sigma_{e}^{2}$.

Rumen measurements were analyzed as repeated measures by using the autoregressive repeated covariance structure in SAS (Version 9.1, SAS Institute Inc.). Model fixed effects included period, treatment, hour, and the treatment $\times$ hour interaction, with cow as the random effect. The linear model for these data is written as follows:

$$
\mathrm{y}_{\mathrm{ijkm}}=\mu+\beta_{\mathrm{i}}+\rho_{\mathrm{j}}+\gamma_{\mathrm{k}}+\alpha_{\mathrm{m}}+\alpha \gamma_{\mathrm{km}}+\varepsilon_{\mathrm{ijkm}},
$$

where $\mathrm{y}_{\mathrm{ijkm}}$ represents observation ${ }_{\mathrm{ijkm}} ; \mu$ represents the overall mean; $\beta_{\mathrm{i}}$ represents the random effect of cow $\mathrm{i}$; 
Table 1. Ingredient and chemical composition of experimental treatments (experiments 1 and 2)

\begin{tabular}{|c|c|c|c|c|}
\hline \multirow[b]{2}{*}{ Ingredient, $\%$ of DM } & \multicolumn{4}{|c|}{ Treatment $^{1}$} \\
\hline & Control & DDGS & Germ & HPDDG \\
\hline Distillers dried grains plus solubles & - & 15.0 & - & - \\
\hline Corn germ & - & - & 15.0 & - \\
\hline High-protein corn distillers grains & - & - & - & 14.4 \\
\hline Corn silage & 26.7 & 26.0 & 26.3 & 25.3 \\
\hline Alfalfa haylage & 10.3 & 5.42 & 5.48 & 5.28 \\
\hline Alfalfa hay & 5.56 & 5.42 & 5.48 & 5.28 \\
\hline Brome hay, chopped & 6.67 & 15.2 & 15.3 & 14.8 \\
\hline Ground corn & 20.7 & 13.9 & 9.42 & 15.2 \\
\hline Soybean meal, $48 \% \mathrm{CP}$ & 8.93 & 6.18 & 8.32 & - \\
\hline SoyPass $^{2}$ & 4.44 & 2.82 & 5.91 & - \\
\hline Whole linted cottonseed & 3.33 & - & - & 6.83 \\
\hline Soybean hulls & 10.4 & 7.38 & 6.13 & 10.0 \\
\hline Urea & - & - & - & 0.21 \\
\hline Tallow & 0.44 & - & - & - \\
\hline Vitamin $\mathrm{ADE}^{3}$ & 0.13 & 0.13 & 0.13 & 0.13 \\
\hline Magnesium oxide & 0.16 & 0.15 & 0.15 & 0.15 \\
\hline Trace mineral ${ }^{4}$ & 0.04 & 0.04 & 0.04 & 0.04 \\
\hline Sel-Plex $1000^{5}$ & 0.02 & 0.02 & 0.02 & 0.02 \\
\hline Vitamin E & 0.02 & 0.02 & 0.02 & 0.02 \\
\hline Limestone & 0.98 & 1.35 & 1.34 & 1.37 \\
\hline Salt & 0.10 & 0.10 & 0.10 & 0.10 \\
\hline Sodium bicarbonate & 1.00 & 0.98 & 0.99 & 0.95 \\
\hline Dicalcium phosphate & 0.18 & - & - & - \\
\hline \multicolumn{5}{|c|}{$\begin{array}{l}{ }^{1} \text { Control }=0 \% \text { DM coproducts; DDGS }=15 \% \text { DM distillers dried grains plus solubles (DG); germ }=15 \% \text { DM } \\
\text { corn germ; HPDDG }=15 \% \text { DM high-protein distillers grains (HP; no solubles included). }\end{array}$} \\
\hline \multicolumn{5}{|l|}{${ }^{2}$ LignoTech (Overland Park, KS). } \\
\hline \multicolumn{5}{|c|}{$\begin{array}{l}{ }^{3} \text { Formulated to supply approximately } 120,000 \mathrm{IU} / \mathrm{d} \text { of vitamin } \mathrm{A}, 24,000 \mathrm{IU} / \mathrm{d} \text { of vitamin } \mathrm{D} \text {, and } 800 \mathrm{IU} / \mathrm{d} \\
\text { vitamin } \mathrm{E} \text { in the total ration. }\end{array}$} \\
\hline \multicolumn{5}{|c|}{${ }^{4}$ Formulated to contain $1.0 \% \mathrm{Ca}, 0.50 \% \mathrm{P}, 0.36 \% \mathrm{Mg}$, and $1.3 \% \mathrm{~K}$. } \\
\hline
\end{tabular}

$\rho_{\mathrm{j}}$ represents the fixed effect of period $\mathrm{j} ; \gamma_{\mathrm{k}}$ represents the fixed effect of hour $\mathrm{k} ; \alpha_{\mathrm{m}}$ represents the fixed effect of treatment $\mathrm{m}$; and $\alpha \gamma_{\mathrm{km}}$ represents the interaction effect between hour $\mathrm{k}$ and treatment $\mathrm{m}$. The residual term $\varepsilon_{i j k m}$ was assumed to be normally, independently, and identically distributed, with variance $\sigma_{e}^{2}$.

Statistical significance for all treatment effects was declared with $P \leq 0.05$, and trends were discussed with $P \leq 0.10$. The PDIFF option was used to separate and compare differences of least squares means when the $P$-value for the treatment effect was $<0.10$. Treatment means are presented as least squares means, and the largest standard errors of the means are reported.

\section{RESULTS}

\section{Forage, Coproduct, and Ration Chemical Composition}

Ingredient compositions of the experimental treatment rations are listed in Table 1. Results of the chemical composition of the forages and coproducts were averaged across experimental treatments and are listed in Tables 2 and 3. Measured chemical compositions for the treatment diets fed in experiment 1 (Table 4) and experiment 2 (Table 5) are listed. The particle sizes of treatment rations are listed in Tables 6 and 7 for experiment 1 and experiment 2, respectively.

\section{DMI, Milk Production, and Milk Composition}

Feed DMI and production results are listed in Table 8 for experiment 1 and Table 9 for experiment 2. In experiment 1 , only DMI of the germ treatment differed from the control treatment ( 24.3 vs. $22.9 \pm 0.61 \mathrm{~kg} / \mathrm{d}$ ). The DMI observed in experiment 2 was not different and averaged $26.1 \pm 2.32 \mathrm{~kg} / \mathrm{d}$ across experimental treatments.

The milk production response in experiment 1 paralleled DMI, with only the germ treatment differing from the control treatment (32.1 vs. $31.5 \pm 1.12 \mathrm{~kg} / \mathrm{d})$. Percentage of fat was not different among treatments and averaged $3.76 \pm 0.10 \%$. Yield of milk fat was similar and averaged $1.15 \pm 0.1 \mathrm{~kg} / \mathrm{d}$ across treatments. In addition, $3.5 \%$ FCM was not different across treatments and averaged $31.7 \pm 1.3 \mathrm{~kg} / \mathrm{d}$. Percentage of protein was similar and averaged $3.0 \pm 0.03 \%$ for all treatments. Yield of milk protein was not different and aver- 
Table 2. Chemical analysis of forages included in experimental treatments ${ }^{1}$

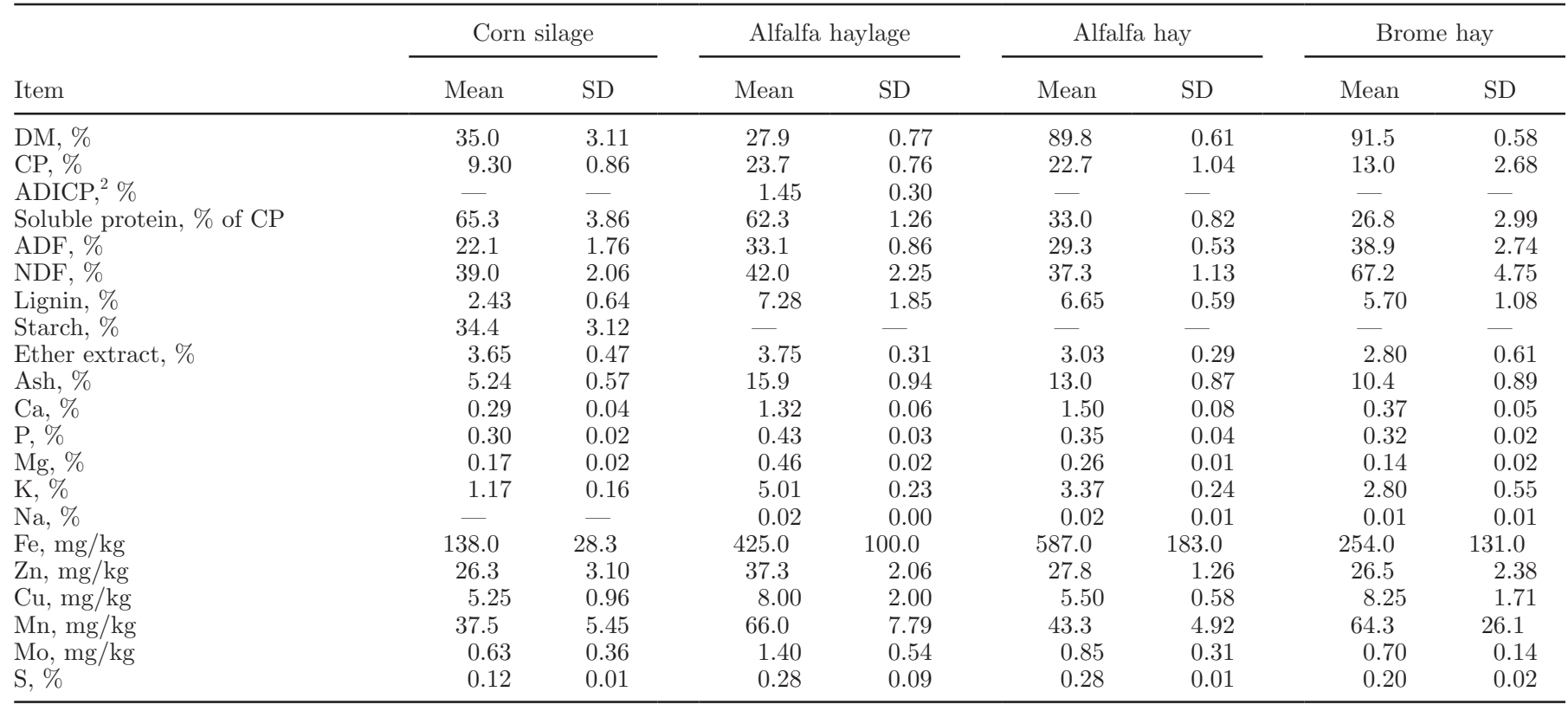

${ }^{1}$ Values determined by Dairy One Forage Testing Laboratory (Ithaca, NY).

${ }^{2}$ Acid detergent insoluble CP.

aged $0.90 \pm 0.03 \mathrm{~kg} / \mathrm{d}$ across treatments. Compared with the control diet, cows consuming HPDDG had a higher concentration of MUN (15.9 vs. $15.0 \pm 0.39 \mathrm{mg} /$ $\mathrm{dL}$ ). Feed efficiency was not different and averaged 1.30 \pm 0.04 across treatments.
In experiment 2, observed milk production was similar and averaged $28.3 \pm 3.92 \mathrm{~kg} / \mathrm{d}$ across treatments. In contrast to experiment 1 , milk production in experiment 2 did not parallel DMI. Percentage of milk fat was not different and averaged $3.28 \pm 0.28 \%$. Yield of milk

Table 3. Chemical analysis of the 3 corn-milling coproducts included in experimental treatments ${ }^{1,2}$

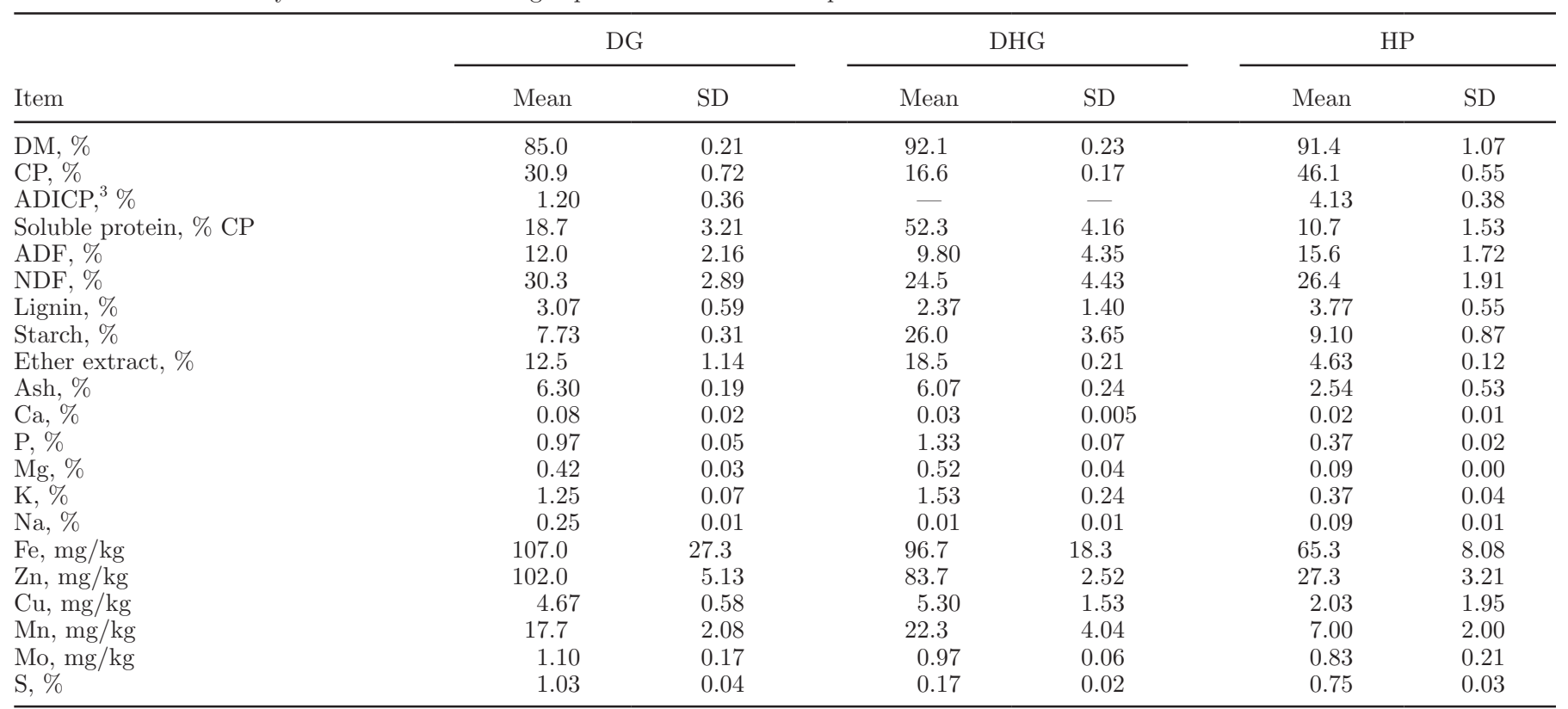

${ }^{1}$ Values determined by Dairy One Forage Testing Laboratory (Ithaca, NY).

${ }^{2} \mathrm{DG}=$ dried distillers grains plus solubles (no heating or cooking before fermentation); DHG = dehydrated corn germ meal; HP $=$ high-protein dried distillers grains (no solubles included).

${ }^{3}$ Acid detergent insoluble CP. 
Table 4. Analyzed chemical composition of experimental treatments (experiment 1)

\begin{tabular}{|c|c|c|c|c|c|c|c|c|}
\hline \multirow{2}{*}{ Item, \% } & \multicolumn{8}{|c|}{ Treatment ${ }^{1,2}$} \\
\hline & \multicolumn{2}{|c|}{ Control } & \multicolumn{2}{|c|}{ DDGS } & \multicolumn{2}{|c|}{ Germ } & \multicolumn{2}{|c|}{ HPDDG } \\
\hline $\mathrm{DM}$ & 58.7 & 2.29 & 63.2 & 2.40 & 62.9 & 3.28 & 64.4 & 2.54 \\
\hline CP & 19.5 & 0.69 & 19.7 & 0.59 & 19.5 & 0.45 & 18.9 & 0.45 \\
\hline NDF & 34.5 & 1.79 & 35.6 & 1.56 & 34.6 & 2.72 & 41.1 & 3.27 \\
\hline Ether extract & 4.50 & 0.51 & 4.50 & 0.17 & 5.50 & 0.20 & 4.80 & 0.39 \\
\hline Starch & 22.9 & 1.67 & 21.8 & 0.69 & 22.3 & 0.17 & 19.9 & 2.42 \\
\hline $\mathrm{NFC}^{3}$ & 33.4 & 1.54 & 31.6 & 1.25 & 31.4 & 2.51 & 27.0 & 3.21 \\
\hline
\end{tabular}

${ }^{1}$ Samples were collected on d 20 and 21 of each period and composited; each mean is representative of 4 composite samples.

${ }^{2}$ Control $=0 \%$ DM coproducts; DDGS $=15 \%$ DM distillers grains plus solubles; germ $=15 \%$ DM corn germ; HPDDG $=15 \%$ DM high-protein distillers grains (no solubles included).

${ }^{3}$ Calculated by difference; NFC $=100-(\mathrm{CP}+$ ether extract + ash $+\mathrm{NDF})$.

fat was similar and averaged $0.95 \pm 0.2 \mathrm{~kg} / \mathrm{d}$. Comparable with experiment 1, 3.5\% FCM was similar across treatments and averaged $27.8 \pm 4.5 \mathrm{~kg} / \mathrm{d}$. Yield of milk protein was similar among treatments and averaged 0.9 $\pm 0.1 \mathrm{~kg} / \mathrm{d}$. In contrast to experiment 1, MUN was not different and averaged $11.2 \pm 1.10 \mathrm{mg} / \mathrm{dL}$ across treatments. Feed efficiency was not different and averaged $1.09 \pm 0.10$ across treatments.

\section{Ruminal pH, VFA Concentrations, and Ammonia-N Concentration}

The effects of feeding rations containing corn-milling coproducts on ruminal VFA and ammonia-N concentrations in experiment 2 are listed in Table 10. Ruminal $\mathrm{pH}$ was not different and averaged $6.26 \pm 0.08$ across treatments. Rumen ammonia- $\mathrm{N}$ concentrations were similar among treatments and averaged $14.1 \pm 0.95$ $\mathrm{mg} / \mathrm{dL}$. Total VFA concentration did not differ among treatments and averaged $125.3 \pm 4.2 \mathrm{mM}$. The concentration of acetate in the rumen for animals consuming the control treatment $(81.7 \mathrm{mM})$ was significantly higher than for the DDGS $(75.8 \mathrm{mM})$, germ $(75.0 \mathrm{mM})$, and HPDDG treatments $(78.4 \mathrm{mM})$. Propionate concentration was similar across treatments and averaged $27.8 \pm 1.2 \mathrm{~m} M$. Concentrations of butyrate $(14.4 \pm 0.89$ $\mathrm{m} M)$ and isobutyrate $(1.53 \pm 0.08 \mathrm{mM})$ were not different across treatments. Concentration of valerate was similar and averaged $2.1 \pm 0.1 \mathrm{~m} M$ across treatments. Isovalerate tended to be highest for the control treatment $(2.1 \mathrm{mM})$ compared with the DDGS $(1.7 \mathrm{mM})$, germ $(1.8 \mathrm{mM})$, and HPDDG treatments $(1.7 \mathrm{mM})$. In addition, compared with the control treatment, the ratio of ruminal acetate to propionate was lower for the DDGS treatment (2.6 vs. $3.0 \pm 0.10$ for DDGS and the control, respectively).

Table 5. Analyzed chemical composition of experimental treatments (experiment 2)

\begin{tabular}{|c|c|c|c|c|c|c|c|c|}
\hline \multirow[b]{2}{*}{ Item, $\%$} & \multicolumn{8}{|c|}{ Treatment ${ }^{1,2}$} \\
\hline & Mean & $\mathrm{SD}$ & Mean & $\mathrm{SD}$ & Mean & $\mathrm{SD}$ & Mean & $\mathrm{SD}$ \\
\hline $\mathrm{DM}$ & 60.1 & 2.28 & 64.8 & 2.32 & 64.5 & 2.15 & 66.1 & 2.34 \\
\hline $\mathrm{CP}$ & 18.2 & 0.98 & 19.1 & 0.43 & 19.3 & 0.69 & 19.9 & 0.52 \\
\hline $\mathrm{NDF}^{3}$ & 37.7 & 1.37 & 39.2 & 1.38 & 36.3 & 1.19 & 41.1 & 1.66 \\
\hline Ether extract & 3.11 & 0.19 & 3.72 & 0.06 & 4.44 & 0.12 & 4.10 & 0.31 \\
\hline Starch & 24.6 & 0.78 & 22.6 & 0.77 & 23.1 & 0.23 & 21.3 & 0.86 \\
\hline $\mathrm{NFC}^{3}$ & 32.7 & 0.60 & 29.5 & 1.51 & 31.5 & 1.58 & 28.1 & 1.44 \\
\hline
\end{tabular}

${ }^{1}$ Samples were collected on d 20 and 21 of each period and composited; each mean is representative of 4 composite samples.

${ }^{2}$ Control $=0 \%$ DM coproducts; DDGS $=15 \%$ DM distillers grains plus solubles; germ $=15 \%$ DM corn germ; HPDDG $=15 \%$ DM high-protein distillers grains (no solubles included).

${ }^{3}$ Calculated by difference; $\mathrm{NFC}=100-(\mathrm{CP}+$ ether extract + ash $+\mathrm{NDF})$. 
Table 6. Effects of feeding corn-milling coproducts on as-fed ration particle size distribution (experiment 1)

\begin{tabular}{lccccc}
\hline & \multicolumn{4}{c}{ Treatment $^{2,3}$} \\
\cline { 2 - 3 } Particle size, ${ }^{1}$ \% retained & Control & DDGS & Germ & HPDDG & SEM $^{4}$ \\
\hline$>19.0 \mathrm{~mm}$ & 12.8 & 12.6 & 12.0 & 16.2 & 0.84 \\
$>8.0$ to $19.0 \mathrm{~mm}$ & 24.5 & 19.5 & 20.3 & 22.1 & 0.48 \\
$>1.18$ to $8.0 \mathrm{~mm}$ & 41.4 & 36.2 & 46.2 & 34.4 & 0.53 \\
$<1.18 \mathrm{~mm}$ & 20.5 & 30.8 & 20.8 & 26.2 & 0.39 \\
1.18 to $>19.0 \mathrm{~mm}$ & 78.7 & 68.2 & 78.4 & 72.6 & 0.35 \\
${ }^{1}$ Particle size determined using the Penn State Particle Separator (Kononoff et al., 2003). \\
${ }^{2}$ Samples were collected on d 20 and 21 of each period and composited; each mean is representative of 4 com- \\
posite samples. \\
${ }^{3}$ Control = $\%$ DM coproducts; DDGS = 15\% DM distillers grains plus solubles; germ = 15\% DM corn germ; \\
HPDDG = 15\% DM high-protein distillers grains (no solubles included). \\
${ }^{4}$ Highest SEM of the MIXED procedure (SAS Institute Inc., Cary, NC) is reported. \\
\end{tabular}

\section{Apparent Nutrient Digestibility of TMR}

Major nutrient digestibility, amount digested, and energy compositions of the rations fed in experiment 2 are listed in Table 11. Dry matter digestibility was not different across treatments and averaged $63.5 \pm 2.71 \%$. Organic matter digestibility was similar and averaged $67.4 \pm 2.14 \%$ across experimental treatments. Neutral detergent fiber digestibility was not different and averaged $43.5 \pm 4.22 \%$. Digestibility of $\mathrm{N}$, ether extract, and NFC were similar across treatments and averaged $65.7 \pm 2.73,85.1 \pm 1.9$, and $96.7 \pm 2.98 \%$, respectively. When percentage of TDN was measured according to NRC (2001), the control treatment $(62.7 \%)$ tended to be similar in TDN to the DDGS treatment $(57.9 \%)$ but higher than the germ (55.5\%) and HPDDG treatments (55.4\%). Net energy for lactation values of the rations followed a pattern similar to TDN and were 1.49, 1.35, 1.27 , and $1.27 \mathrm{Mcal} / \mathrm{kg}$ for the control, DDGS, germ, and HPDDG treatments.

\section{Urine $P D$ and Creatinine Excretion}

The concentration and excretion of urinary PD and creatinine of animals fed in experiment 2 are listed in Table 12. No treatment differences were observed for concentrations of allantoin, uric acid, total PD, or creatinine. Allantoin concentration averaged $8.0 \pm$ $0.8 \mathrm{~m} M$ across treatments. Concentration of uric acid averaged $1.0 \pm 0.2 \mathrm{mM}$, and the sum of allantoin and uric acid concentrations averaged $9.0 \pm 1.0 \mathrm{~m} M$ across treatments. Xanthine was not detected for any treatment, and compared with the control treatment $(0.14$ $\mathrm{mM})$, concentration of hypoxanthine was higher for the DDGS $(0.76 \mathrm{~m} M)$ and HPDDG treatments $(0.84 \mathrm{mM})$. Excretion of allantoin was similar among treatments and averaged $265.2 \pm 38.9 \mathrm{mmol} / \mathrm{d}$. Total PD excretion was also similar across treatments and averaged 296.1 $\pm 38.5 \mathrm{mmol} / \mathrm{d}$. In addition, excretion of creatinine was similar across treatments and averaged $174.6 \pm 4.9$ $\mathrm{mmol} / \mathrm{d}$. The ratio of total PD to creatinine was similar $(1.69 \pm 0.21)$ among treatments and was used to estimate differences in microbial CP production (MCP). Treatment estimates of MCP averaged 1,161.2 \pm 182.2 $\mathrm{g} / \mathrm{d}$.

\section{DISCUSSION}

Reports of using corn-milling coproducts to replace portions of forages and concentrates in lactating dairy

Table 7. Effects of feeding corn-milling coproducts on as-fed ration particle size distribution (experiment 2)

\begin{tabular}{lccccc}
\hline & \multicolumn{4}{c}{ Treatment $^{2,3}$} \\
\cline { 2 - 4 } Particle size, ${ }^{2,}$ \% retained & Control & DDGS & Germ & HPDDG & SEM $^{4}$ \\
\hline$>19.0 \mathrm{~mm}$ & 14.4 & 12.4 & 12.4 & 14.0 & 0.70 \\
$>8.0$ to $19.0 \mathrm{~mm}$ & 26.6 & 19.8 & 21.3 & 25.1 & 0.70 \\
$>1.18$ to $8.0 \mathrm{~mm}$ & 39.8 & 35.6 & 46.2 & 33.6 & 0.54 \\
$<1.18 \mathrm{~mm}$ & 18.5 & 31.6 & 19.5 & 26.4 & 0.78 \\
1.18 to $>19.0 \mathrm{~mm}$ & 80.8 & 67.7 & 79.8 & 72.6 & 0.78 \\
\hline
\end{tabular}

${ }^{1}$ Particle size determined using the Penn State Particle Separator (Kononoff et al., 2003).

${ }^{2}$ Samples were collected on d 20 and 21 of each period and composited; each mean is representative of 4 composite samples.

${ }^{3}$ Control $=0 \%$ DM coproducts; DDGS $=15 \%$ DM distillers grains plus solubles; germ $=15 \%$ DM corn germ; $\mathrm{HPDDG}=15 \%$ DM high-protein distillers grains (no solubles included).

${ }^{4}$ Highest SEM is reported. 
Table 8. Effects of feeding corn-milling coproducts on milk yield and composition (experiment 1)

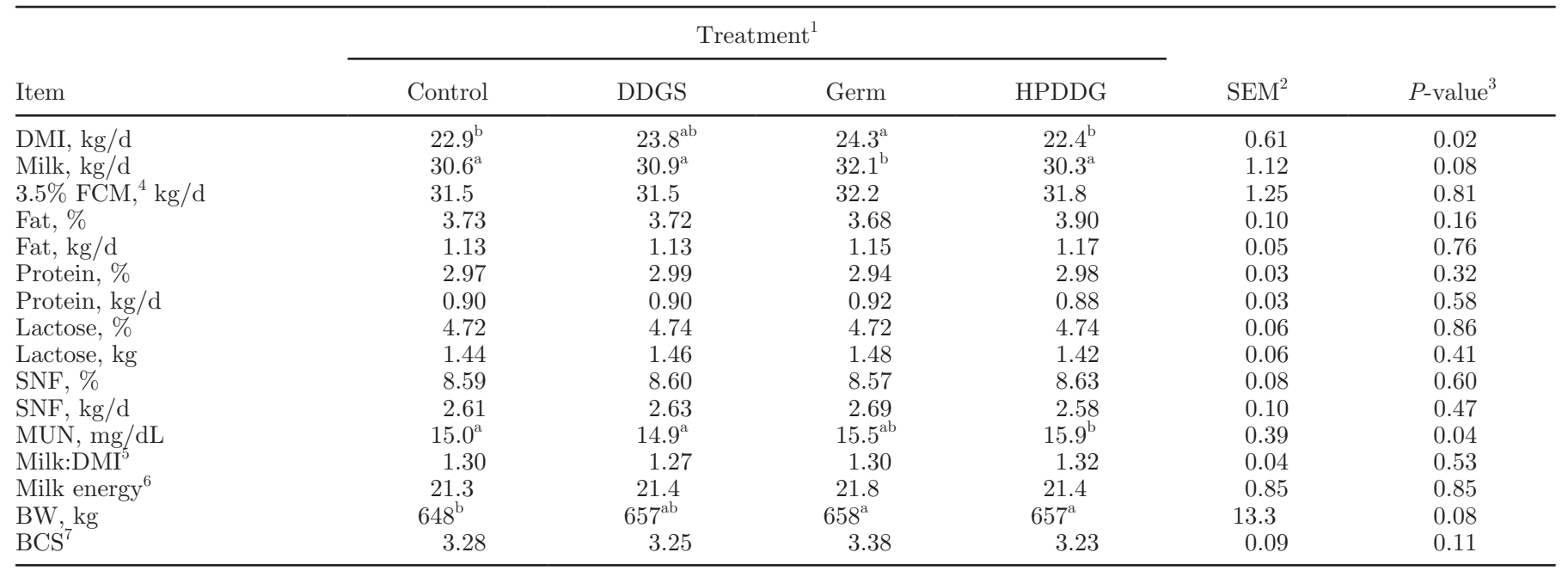

${ }^{\mathrm{a}, \mathrm{b}}$ Values in the same row with different superscripts differ $(P<0.05)$.

${ }^{1}$ Control $=0 \%$ DM coproducts; DDGS $=15 \%$ DM distillers grains plus solubles; germ $=15 \%$ DM corn germ; HPDDG $=15 \%$ DM high-protein distillers grains (no solubles included).

${ }^{2}$ Highest SEM is reported.

${ }^{3}$ Main effect of the treatment.

${ }^{4} \mathrm{FCM}$ calculated as $[$ milk fat $(\mathrm{kg}) \times 16.218]+[$ milk yield $(\mathrm{kg} / \mathrm{d}) \times 0.4324]$.

${ }^{5}$ Feed efficiency calculated as milk:DMI.

${ }^{6}$ Milk energy (Mcal $/ \mathrm{kg}$ per day) calculated as $(0.0929 \times$ milk fat $\%+0.0563 \times$ milk protein $\%+0.0395 \times$ lactose $\%) \times$ milk yield $(\mathrm{kg} / \mathrm{d})$.

${ }^{7}$ Cow BCS determined on a 1 to 5 scale according to Wildman et al. (1982).

Table 9. Effects of feeding corn-milling coproducts on milk yield and composition (experiment 2)

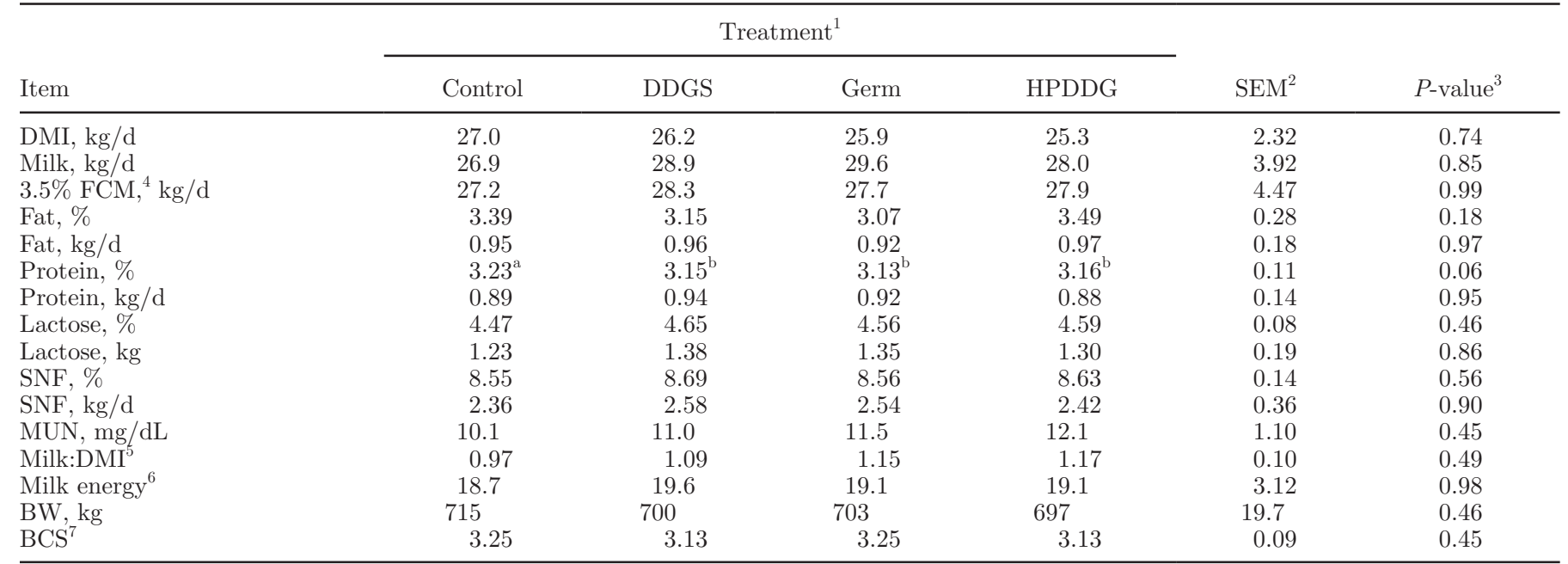

${ }^{\mathrm{a}, \mathrm{b}}$ Values in the same row with different superscripts differ $(P<0.05)$.

${ }^{1}$ Control $=0 \%$ DM coproducts; DDGS $=15 \%$ DM distillers grains plus solubles; germ $=15 \%$ DM corn germ; HPDDG $=15 \%$ DM high-protein distillers grains (no solubles included).

${ }^{2}$ Highest SEM is reported.

${ }^{3}$ Main effect of the treatment.

${ }^{4}$ Calculated as [milk fat $\left.(\mathrm{kg}) \times 16.218\right]+[$ milk yield $(\mathrm{kg} / \mathrm{d}) \times 0.4324]$.

${ }^{5}$ Feed efficiency calculated as milk:DMI.

${ }^{6}$ Milk energy (Mcal $/ \mathrm{kg}$ per day) calculated as $(0.0929 \times$ milk fat $\%+0.0563 \times$ milk protein $\%+0.0395 \times$ lactose $\%) \times$ milk yield $(\mathrm{kg} / \mathrm{d})$.

${ }^{7}$ Cow BCS determined on a 1 to 5 scale according to Wildman et al. (1982). 
Table 10. Effects of feeding corn-milling coproducts on VFA and $\mathrm{NH}_{4}$ concentrations (experiment 2)

\begin{tabular}{|c|c|c|c|c|c|c|}
\hline Item & \multicolumn{4}{|c|}{ Treatment $^{1}$} & $\mathrm{SEM}^{2}$ & $P$-value ${ }^{3}$ \\
\hline $\mathrm{pH}$ & 6.36 & 6.16 & 6.29 & 6.21 & 0.08 & 0.19 \\
\hline Total VFA, mM & 130.3 & 125.0 & 121.6 & 124.5 & 4.17 & 0.30 \\
\hline Acetate, $\mathrm{m} M$ & $81.7^{\mathrm{a}}$ & $75.8^{\mathrm{b}}$ & $75.0^{\mathrm{b}}$ & $78.4^{\mathrm{b}}$ & 2.77 & 0.05 \\
\hline Propionate, $\mathrm{m} M$ & 27.5 & 29.7 & 26.6 & 27.3 & 1.24 & 0.27 \\
\hline Isovalerate, $\mathrm{m} M$ & $2.13^{\mathrm{a}}$ & $1.74^{\mathrm{b}}$ & $1.78^{\mathrm{b}}$ & $1.70^{\mathrm{b}}$ & 0.12 & 0.06 \\
\hline Acetate:propionate & $3.02^{\mathrm{a}}$ & $2.62^{\mathrm{b}}$ & $2.88^{\mathrm{a}}$ & $2.91^{\mathrm{a}}$ & 0.10 & 0.03 \\
\hline
\end{tabular}

${ }^{\mathrm{a}, \mathrm{b}}$ Values in the same row with different superscripts differ $(P<0.05)$.

${ }^{1}$ Control $=0 \%$ DM coproducts; DDGS $=15 \%$ DM distillers grains plus solubles; germ $=15 \%$ DM corn germ; HPDDG $=15 \%$ DM high-protein distillers grains (no solubles included).

${ }^{2}$ Highest SEM is reported.

${ }^{3}$ Main effect of the treatment. $P<0.05$ are significantly different; $P \leq 0.10$ are considered a trend.

cow rations have demonstrated that these feeds may be effectively included in rations fed to lactating cows without deleterious effects on production (Anderson et al., 2006; Kleinschmit et al., 2006). In experiment 1, cows consuming rations containing DG and HP coproducts consumed similar amounts of feed as cows consuming the control ration. In addition, these treatment rations resulted in similar milk production and composition when compared with the control ration, suggesting that the partial replacement of alfalfa, soybean meal, and ground corn with these coproducts still maintained the required supply of net energy and MP. Cows consuming

Table 11. Effects of feeding corn-milling coproducts on ration component digestibility and energy composition (experiment 2)

\begin{tabular}{|c|c|c|c|c|c|c|}
\hline Measurement & \multicolumn{4}{|c|}{ Treatment $^{1}$} & $\mathrm{SEM}^{2}$ & $P$-value ${ }^{3}$ \\
\hline DM & 68.1 & 63.8 & 61.7 & 60.6 & 2.71 & 0.18 \\
\hline OM & 71.5 & 67.7 & 66.2 & 64.4 & 2.14 & 0.21 \\
\hline $\mathrm{NDF}$ & 49.0 & 43.8 & 40.3 & 40.9 & 4.22 & 0.35 \\
\hline $\mathrm{CP}$ & 67.5 & 66.9 & 65.2 & 63.1 & 2.73 & 0.64 \\
\hline \multicolumn{7}{|l|}{ Digested, $\mathrm{kg} / \mathrm{d}$} \\
\hline DM & 18.4 & 16.9 & 16.0 & 15.7 & 2.08 & 0.35 \\
\hline $\mathrm{OM}$ & 17.6 & 16.3 & 15.7 & 15.4 & 1.81 & 0.49 \\
\hline $\mathrm{NDF}$ & 4.96 & 4.65 & 3.81 & 4.38 & 0.80 & 0.45 \\
\hline $\mathrm{CP}$ & 3.33 & 3.38 & 3.26 & 3.21 & 0.40 & 0.94 \\
\hline $\mathrm{N}$ & 0.53 & 0.54 & 0.52 & 0.51 & 0.06 & 0.94 \\
\hline Ether extract & $0.71^{\mathrm{a}}$ & $0.85^{\mathrm{ab}}$ & $0.99^{\mathrm{b}}$ & $0.88^{\mathrm{ab}}$ & 0.10 & 0.07 \\
\hline $\mathrm{NE}_{\mathrm{L}},{ }^{8} \mathrm{Mcal} / \mathrm{kg}$ & 1.49 & 1.35 & 1.27 & 1.27 & 0.06 & 0.13 \\
\hline
\end{tabular}

${ }^{\mathrm{a}, \mathrm{b}}$ Values in the same row with different superscripts differ $(P<0.05)$.

${ }^{1}$ Control $=0 \%$ DM coproducts; DDGS $=15 \%$ DM distillers grains plus solubles; germ $=15 \%$ DM corn germ; HPDDG $=15 \%$ DM high-protein distillers grains (no solubles included).

${ }^{2}$ Highest SEM is reported.

${ }^{3}$ Main effect of the treatment. $P<0.05$ are significantly different; $P \leq 0.10$ are considered a trend.

${ }^{4}$ Calculated as $100-(\% \mathrm{CP}+\%$ ether extract $+\%$ ash $+\% \mathrm{NDF})$.

${ }^{5}$ Total digestible nutrients measured according to NRC (2001).

${ }^{6}$ Digestible energy content calculated according to NRC (2001), using measured TDN values.

${ }^{7} \mathrm{ME}$ content calculated according to NRC (2001), using measured TDN values.

${ }^{8}$ Calculated according to NRC (2001), using measured TDN values. 
Table 12. Effects of feeding corn-milling coproducts on daily excretion of urinary creatinine, allantoin, uric acid, and hypoxanthine and rumen microbial CP synthesis (experiment 2)

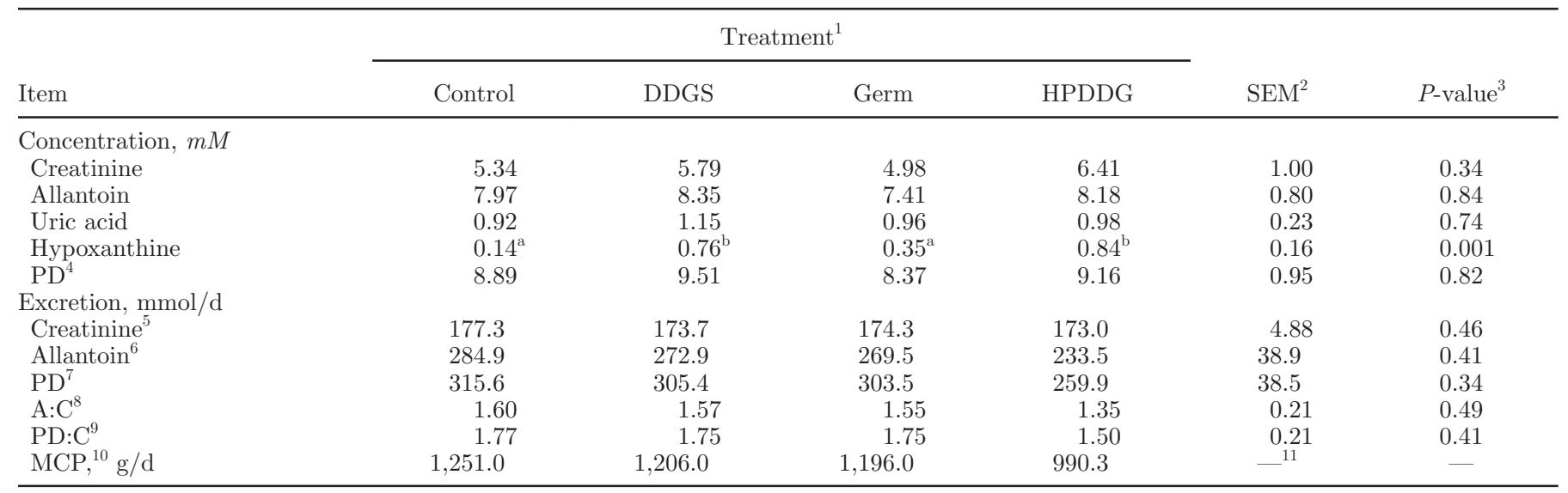

${ }^{\mathrm{a}, \mathrm{b}}$ Values in the same row with different superscripts differ $(P<0.05)$.

${ }^{1}$ Control $=0 \%$ DM coproducts; DDGS $=15 \%$ DM distillers grains plus solubles; germ $=15 \%$ DM corn germ; HPDDG $=15 \%$ DM high-protein distillers grains (no solubles included).

${ }^{2}$ Highest SEM is reported.

${ }^{3}$ Main effect of the treatment. $P<0.05$ are significantly different; $P \leq 0.10$ are considered a trend.

${ }^{4}$ Total concentration of purine derivatives.

${ }^{5}$ Excretion of creatinine $=[28 \times \mathrm{BW}(\mathrm{kg}) / 113.1]$

${ }^{6}$ Excretion of allantoin $=$ creatinine excretion $\times \mathrm{A}: \mathrm{C}$.

${ }^{7}$ Excretion of total purine derivatives $=$ creatinine excretion $\times \mathrm{PD}: \mathrm{C}$.

${ }^{8}$ Ratio of allantion excretion to creatinine excretion.

${ }^{9}$ Ratio of total purine derivative excretion to creatinine excretion.

${ }^{10}$ Microbial CP as estimated by Chen and Gomes (1992).

${ }^{11}$ Statistical test of treatment on microbial CP production was not conducted because values were an estimated concentration of PD.

germ tended to consume more feed and tended to produce more milk (32.1 vs. $30.6 \pm 1.12 \mathrm{~kg} / \mathrm{d})$ than those consuming the control ration. It is possible that the higher fat content of this ration resulted in a greater supply of energy and thus allowed animals to produce more milk while consuming less feed.

In the second experiment, both feed intake and milk production did not follow patterns identical to those observed in the first experiment; however, given the small sample size, treatment differences were not expected for these variables. Additionally, the average fat concentration of milk fat in the first experiment was greater than in the second experiment (3.75 vs. $3.20 \%$ ). Although differences between experiments cannot be tested, it is likely that this was because the second study was conducted during warmer summer months, and it is well known that heat stress affects milk fat synthesis (West, 2003). More specifically, the main objective of the second experiment was to evaluate how the inclusion of corn-milling coproducts might affect rumen fermentation and total-tract nutrient digestibility when compared with inclusion of the control ration.

When compared with the control treatment, ruminal $\mathrm{pH}$ was not different with the inclusion of any coproduct and averaged $6.26 \pm 0.08$ across treatments. A major factor known to affect rumen $\mathrm{pH}$ is level of NFC (Rus- sell et al., 1992). Although rations including coproducts contained slightly less NFC, it is likely that differences were not great enough to affect rumen $\mathrm{pH}$. In addition, the NDF content and particle size were similar, thus ensuring that the level of effective fiber was similar between treatments. Although concentration of total rumen VFA was similar across treatments, the concentration of acetate was reduced when animals consumed treatments containing coproducts when compared with the control treatment. Consequently, the ratio of acetate to propionate was also lower, yielding effects similar to the observations of Sasikala-Appukuttan et al. (2008). The higher concentration of rumen acetate for the control diet compared with diets containing coproducts was likely due to its higher concentration of TDN (Table 11). This association has long been noted (Hinders and Owen, 1963). Unfortunately, in the current experiment, no significant treatment effects were observed on individual nutrient components of TDN; thus, it is difficult to determine the cause of the shift in rumen fermentation. Likely, a portion of the reduction of ration TDN in diets containing coproducts was due to the increase in the proportion of lower quality brome hay, making these treatments less digestible than the control treatment. Decreased isovalerate concentration in diets containing coproducts was consistent with 
previous observations. Anderson et al. (2006) observed decreased isovalerate concentrations with diets containing 10 and $20 \%$ dry distillers grains and wet distillers grains (both containing solubles) compared with the control ration containing $0 \%$ coproducts (1.3 vs. $1.5 \pm$ $0.11 \mathrm{~m} M$ for DG rations vs. the control). Schingoethe et al. (1999; 1.4 vs. $1.7 \pm 0.06 \mathrm{mM}$ for DG vs. control) and Nichols et al. (1998; 1.7 vs. $2.0 \pm 0.09 \mathrm{mM}$ for DG vs. soybean meal) also observed decreased isovalerate concentrations when feeding distillers grains to lactating dairy cattle. The decreased production of branched-chain fatty acids may be attributed to the overall low concentrations of branched-chain AA present in diets containing high amounts of corn products (Schingoethe et al., 1999); thus, the control ration may contain more precursors for branched-chain fatty acid synthesis (Johnson et al., 1994).

Determination of urine PD excretion is considered a noninvasive, indirect method for estimating differences in rumen microbial protein production (Moorby et al., 2006). In experiment 2, xanthine was not detected, and hypoxanthine concentrations were low across diets (less than $1 \mathrm{mM}$ ). This observation is consistent with the literature, which suggests that high activity of the enzyme xanthine oxidase, which is present in intestinal mucosal cells of cattle, oxidizes and degrades xanthine and hypoxanthine to uric acid before the molecules reach the liver for excretion (Gonzalez-Ronquillo et al., 2004). The total excretion of PD was observed to be similar and averaged $296.1 \pm 38.5 \mathrm{~mm} / \mathrm{d}$ across treatments. This finding would result in a predicted flow of $1160.8 \mathrm{~g} / \mathrm{d}$ of MCP. Treatment effects of MCP were not tested, as recommended by Firkins et al. (2006), because they are predictions based on an algebraic equation, and this estimate contains only the error associated with measurement of urinary PD. Nonetheless, results of the current experiment suggest that compared with the control diet, the inclusion of coproducts in each diet did not affect duodenal MCP flow in lactating cows. It is interesting to note that the concentrations of hypoxanthine were higher for rations that included DDGS and HPDDG, which can be attributed to the residual yeast cells from the industrial corn-ethanol fermentation process found in these coproducts. Similar observations have been made by Janicek et al. (2008), and the higher hypoxanthine may be due to the existence of this $\mathrm{PD}$ in yeast cells, which were likely present in the DG and HP coproducts (Ferreira et al., 1999).

\section{CONCLUSIONS}

This experiment indicates that dairy rations can be successfully formulated to include $15 \%$ of diet DM as corn-milling coproducts while maintaining yields of milk and milk components. Diets formulated to contain coproducts at these levels did not result in major differences in rumen fermentation or digestibility. Decreases in rumen acetate concentration and TDN in diets containing coproducts were likely a result of the addition of grass hay, which was included to increase diet effective fiber levels. These experiments demonstrate that coproducts can be fed at higher levels as alternative energy and protein feed sources. With current increases in feed and production expenses in the dairy industry, coproducts may be used as cost-effective alternative sources of energy, protein, and fiber to replace more expensive feedstuffs. The ration-balancing methods used in this experiment should allow dairy producers flexibility to incorporate different corn-milling coproducts into lactating dairy rations, which may reduce ration costs.

\section{ACKNOWLEDGMENTS}

The authors thank the personnel at the University of Nebraska Dairy Research Unit (Mead, NE) for care of the experimental animals and A. Geis, B. Janicek, C. Mullins, and Z. Alger from the University of NebraskaLincoln for sampling and laboratory assistance.

\section{REFERENCES}

Anderson, J. L., D. J. Shingoethe, K. F. Kalscheur, and A. R. Hippen. 2006. Evaluation of dried and wet distillers grains included at two concentrations in the diets of lactating dairy cows. J. Dairy Sci. 89:3133-3142.

AOAC. 1996. Official Methods of Analysis of AOAC International. 16th ed. Assoc. Off. Anal. Chem., Arlington, VA.

AOAC. 2000. Official Methods of Analysis of AOAC International. 17th ed. Assoc. Off. Anal. Chem., Arlington, VA.

Boston, R. C., D. G. Fox, C. J. Sniffen, R. Janczewski, R. Munsen, and W. Chalupa. 2000. The conversion of a scientific model describing dairy cow nutrition and production to an industry tool: The CPM Dairy project. Pages 361-377 in Modelling Nutrient Utilization in Farm Animals. J. P. McNamara, J. France, and D. Beever, ed. CABI Publishing, Oxford, UK.

Broderick, G. A., and J. H. Kang. 1980. Automated simultaneous determination of ammonia and total amino acids in ruminal fluid and in vitro media. J. Dairy Sci. 63:64-75.

Chen, X. B., and M. J. Gomes. 1992. Estimation of microbial protein supply to sheep and cattle based on urinary excretion of purine derivatives: An overview of the technical details. Int. Feed. Res. Unit Occas. Publ. Rowett Research Institute, Bucksburn, Aberdeen, UK.

Corredor, D. Y., S. R. Bean, T. Schober, and D. Wang. 2006. Effect of decorticating sorghum on ethanol production and composition of DDGS. Cereal Chem. 83:17-21.

Ferreira, T., J. Chevallier, P. Paumard, C. Napias, and D. Brèthes. 1999. Screening of an intragenic second-site suppressor of purinecytosine permease from Saccharomyces cerevisiae: Possible role of Ser272 in the base translocation process. Eur. J. Biochem. $260: 22-30$.

Firkins, J. L., A. N. Hristov, M. B. Hall, G. A. Varga, and N. R. StPierre. 2006. Integration of ruminal metabolism in dairy cattle. J. Dairy Sci. 89(E Suppl.):E31-E51.

Gonda, H. L. 1995. Nutritional status of ruminants determined from excretion and concentration of metabolites in body fluids. PhD 
Diss. Swedish Univ. Agric. Sci., Dept. Anim. Nutr. Manage., Uppsala, Sweden.

Gonzalez-Ronquillo, M., J. Balcells, A. Berenguer, C. Castrillo, and M. Mota. 2004. A comparison of purine derivatives excretion with conventional methods as indices of microbial yield in dairy cows. J. Dairy Sci. 87:2211-2221.

Heinrichs, A.J, and V. Ishler. 2000. Evaluating forage quality by visual appraisal, pH and dry matter content. Coop. Ext. Tech. Bull. DAS 00-7. College of Agriculture Science, The Pennsylvania State University, University Park.

Hinders, R. G., and F. G. Owen. 1963. Relationships between efficiency of milk production and ruminal volatile fatty acids of cows fed isocaloric (ENE) rations of varied concentrate levels. J. Dairy Sci. 46:1246-1250.

Huhtanen, P., K. Kaustell, and S. Jaakkola. 1994. The use of internal markers to predict total digestibility and duodenal flow of nutrients in cattle given six different diets. Anim. Feed Sci. Technol. 48:211-227.

Janicek, B. N., P. J. Kononoff, A. M. Gehman, and P. H. Doane. 2008. The effect of feeding dried distillers grains plus solubles on milk production and excretion of urinary purine derivatives. J. Dairy Sci. 91:3544-3553

Johnson, T. R., M. J. Cecava, E. B. Sheiss, and K. D. Cunningham. 1994. Additions of ruminally degradable crude protein and branched-chain volatile fatty acids to diets containing hydrolyzed feather meal and bloodmeal for lactating cows. J. Dairy Sci. $77: 3676-3682$

Jones, S. J., D. L. Starkey, C. R. Calkins, and J. D. Crouse. 1990. Myofibrillar protein turnover in feed-restricted and realimented beef cattle. J. Anim. Sci. 68:2707-2717.

Kleinschmit, D. H., D. J. Schingoethe, K. F. Kalscheur, and A. R. Hippen. 2006. Evaluation of various sources of corn dried distillers grains plus solubles for lactating dairy cattle. J. Dairy Sci. 89:4784-4794.

Kononoff, P. J., and K. J. Hanford. 2006. Technical note: Estimating statistical power of mixed models used in dairy nutrition experiments. J. Dairy Sci. 89:3968-3971.

Kononoff, P. J., A. J. Heinrichs, and D. R. Buckmaster. 2003. Modification of the Penn State forage and total mixed ration particle separator and the effects of moisture content on its measurements. J. Dairy Sci. 86:1858-1863.

Leonardi, C., S. Bertics, and L. E. Armentano. 2005. Effect of increasing oil from distillers grains or corn oil on lactation performance. J. Dairy Sci. 88:2820-2827.

Leonardi, C., M. Stevenson, and L. E. Armentano. 2003. Effect of two levels of crude protein and methionine supplementation on performance of dairy cows. J. Dairy Sci. 86:4033-4042.

McCarthy, F. D., W. G. Bergen, and D. R. Hawkins. 1983. Muscle protein turnover in cattle of differing genetic backgrounds as measured by urinary Nr-methylhistidine excretion. J. Nutr. 113:2455-2463.

Moorby, J. M., R. J. Dewhurst, R. T. Evans, and J. L. Danelon 2006. Effects of dairy cow diet forage proportion on duodenal nutrient supply and urine purine derivative excretion. J. Dairy Sci. 89:3552-3562.

Murthy, G. S., E. D. Sall, S. G. Metz, G. Foster, and V. Singh. 2008. Evaluation of a dry corn fractionation process for ethanol production with different hybrids. Ind. Crops Prod. In press.

Murthy, G. S., V. Singh, D. B. Johnston, K. D. Rausch, and M. E. Tumbleson. 2006. Evaluation and strategies to improve fermentation characteristics of modified dry-grind corn processes. Cereal Chem. 83:455-459.

NRC. 2001. Nutrient Requirements of Dairy Cattle. 7th rev. ed. Natl. Acad. Press, Washington, DC.

Nichols, J. R., D. J. Schingoethe, H. A. Maiga, M. J. Brouk, and M. S. Piepenbrink. 1998. Evaluation of corn distillers grains and ruminally protected lysine and methionine for lactating dairy cows. J. Dairy Sci. 81:482-491.
Ponnampalam, E., D. B. Steele, D. Burgdorf, and D. McCalla. 2004 Effect of germ and fiber removal on production of ethanol from corn. Appl. Biochem. Biotechnol. 115:837-842.

Roe, M. B., and C. J. Sniffen. 1990. Techniques for measuring protein fractions in feedstuffs. Pages 81-88 in Proc. Cornell Nutr. Conf., Rochester, NY. Cornell University, Ithaca, NY.

Russell, J. B., J. D. O'Connor, D. G. Fox, P. J. Van Soest, and C. J. Sniffen. 1992. A net carbohydrate and protein system for evaluating cattle diets: I. Ruminal fermentation. J. Anim. Sci 70:3551-3561.

Sasikala-Appukuttan, A. K., D. J. Shingoethe, A. R. Hippen, K. F. Kalscheur, K. Karges, and M. L. Gibson. 2008. The feeding value of corn distillers solubles for lactating dairy cows. J. Dairy Sci. 91:279-287.

Schingoethe, D. J., M. J. Brouk, and C. P. Birkelo. 1999. Milk production and composition from cows fed wet corn distillers grains. J. Dairy Sci. 82:574-580.

Shingfield, K. J., and N. W. Offer. 1998. Evaluation of the spot urine sampling technique to assess urinary purine derivative excretion in lactating dairy cows. Anim. Sci. 66:557-568.

Shingfield, K. J., and N. W. Offer. 1999. Simultaneous determination of purine metabolites, creatinine, and pseudouridine in ruminant urine by reversed-phase high-performance liquid chromatography. J. Chromatogr. B, Analyt. Technol. Biomed. Life Sci. 723:81-94.

Sirois, P. K., M. J. Reuter, C. M. Laughlin, and P. J. Lockwood 1994. A method for determining macro and micro elements in forages and feeds by inductively coupled plasma atomic emission spectrometry. Spectroscopist 3:6-9.

Smith, D. 1969. Removing and analyzing total nonstructural carbohydrates from plant tissue. Wisconsin Agric. Exp. Sta. Res. Rep. 41. Wisconsin Agricultural Experiment Station, Madison.

Valadares, R. F. D., G. A. Broderick, S. C. Valadares Filho, and M. K. Clayton. 1999. Effect of replacing alfalfa silage with high moisture corn on ruminal protein synthesis estimated from excretion of total purine derivatives. J. Dairy Sci. 82:2686-2696.

Van Soest, P. J., J. B. Robertson, and B. A. Lewis. 1991. Symposium Carbohydrate methodology, metabolism, and nutritional implications in dairy cattle. Methods for dietary fiber, neutral detergent fiber, and nonstarch polysaccharides in relation to animal nutrition. J. Dairy Sci. 74:3583-3597.

VanBaale, M. J., J. E. Shirley, E. C. Titgemeyer, A. F. Park, M. J. Meyer, R. U. Lindquist, and R. T. Ethington. 2001. Evaluation of wet corn gluten feed in diets for lactating dairy cows. J. Dairy Sci. 84:2478-2485

Vanzant, E. S., R. C. Cochran, and E. C. Titgemeyer. 1998 Standardization of in situ techniques for ruminant feedstuff evaluation. J. Anim. Sci. 76:2717-2729.

Wang, P., V. Singh, H. Xue, D. B. Johnston, K. D. Rausch, and M. E. Tumbleson. 2007. Comparison of raw starch hydrolyzing enzyme with conventional liquefaction and saccharification enzymes in dry-grind corn processing. Cereal Chem. 84:10-14.

Weiss, W. P., H. R. Conrad, and N. R. St. Pierre. 1992. A theoretically based model for predicting total digestible nutrient values of forages and concentrates. Anim. Feed Sci. Technol. 39:95-110.

West, J. W. 2003. Effects of heat-stress on production in dairy cattle. J. Dairy Sci. 86:2131-2144.

Whittet, K. M. 2004. Factors affecting variability in urinary creatinine and purine derivative excretion in beef cattle. MS Diss. Univ. of Nebraska-Lincoln.

Wildman, E. E., G. M. Jones, P. E. Wagner, H. F. Troutt, and T. N. Lesch. 1982. A dairy cow body condition scoring system and its relationship to selected production characteristics. J. Dairy Sci. 65:495-501.

Yang, C.-M. J., and G. A. Varga. 1989. Effect of three concentrate feeding frequencies on rumen protozoa, rumen digesta kinetics, and milk yield in dairy cows. J. Dairy Sci. 72:950-957. 